\title{
Synthesis and Evaluation of Antibacterial Activities of some Important Bridge-head Nitrogenous Heterocyclic Compounds
}

\author{
Shakir M. Saied \\ Department of Pharmacy \\ Institute of Technical \\ Mosul, Iraq \\ Email: shakirmsaied@yahoo.com
}

(Received 8/5/2012 ; Accepted 11/6/2012)

\begin{abstract}
The key intermediates in the present study to synthesize the title bridge-head nitrogen heterocycle compounds were $\mathrm{N}$-substituted semicarbazides 2(a-c), which prepared by hydrazinolysis of the ethyl substituted carbamates 1(a-c) with hydrazine hydrate. These carbamates were prepared by the reaction of proper amines and ethylchloroformate.

The reaction of these semicarbazides with ethanolic solution of carbon disulfide under strong basic conditions at room temperature, followed by acidification resulted in the formation of the corresponding potassium (2-arylcarbamoyl)hydrazine carbodithioate 3(ac), while refluxing the ethanolic solution for three hours afforded 5-(arylamino)-1,3,4oxadiazole-2- thioles $4(\mathrm{a}-\mathrm{c})$. The potassium salts $3(\mathrm{a}-\mathrm{c})$ were cyclized with hydrazine hydrate to 4-amino-5-arylamino-1,2,4-triazole-3-thiones(thioles) 5(a-c).

Compounds 5(a-c) were excellent precursors for 3-(arylamino)-[1,2,4]triazolo[3,4b] $[1,3,4]$ thiadiazoles $6(\mathrm{a}-\mathrm{c})$ by dehydrative ring closure of the proper triazole with formic acid in benzene in presence of phosphorous oxychloride or using microwave irradiation technique.

Also, refluxing of the proper triazoles with carbon disulfide under basic conditions afforded 3-(arylamino)-[1,2,4]triazolo[3,4-b][1,3,4]thiadiazole-6-thiones 7(a-c). Finally 4amino-3-(4-(5-(4-amino-5-thioxo-4,5-dihydro-1H-1,2,4-triazol-3-ylamino)-1,3,4-thiadiazol2-yl)phenylamino)-1H-1,2,4-triazole-5(4H)-thione 5(d) were synthesized by the same procedures that were followed to synthesize its analogs starting from 5-(4-aminophenyl)1,3,4-thiadiazole-2-amine and duplicated all the scales of the reactants.

The structures of these compounds were confirmed by their physical properties in addition to the IR, UV and NMR spectra. All synthesized compounds were tested for their in vitro growth inhibitory activity against a panel of standard strains of pathogenic microorganism including bacteria Staphylococcus, Streptococcus and Salmonella.

All these compounds were practically inactive against the tested microorganisms.
\end{abstract}

Keywords: Bridge-head Nitrogen Heterocycles, Ethyl substituted carbamates, $\mathrm{N}$-substituted semicarbazides, amino-1,3,4-oxadiazole-2-thiones. 


\section{تشييد وقيم الفمالية المضالة للجرالثيم لبهض المركبلت الحلفية غير المتجلنة المهمة

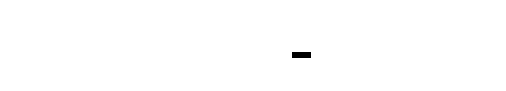

\section{الملضص}

المواد الوسطية المفتاح لهذه الدرلسة لتحضير المركبلت الحقية غير المتجان سلة المهم ـة ذات رلسٔ -

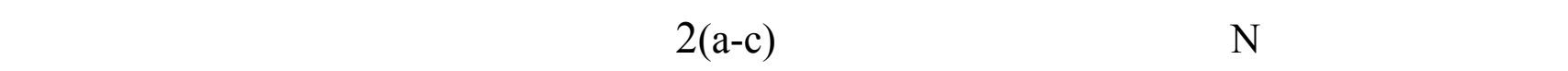
الكاربملت

1(c-a) كبريتيد الكاربون تمتظظروف قاعدية قوية وبدرجة حرارة الغرفة وبعد التحميض تكون 2 - اريل كاربلمويل

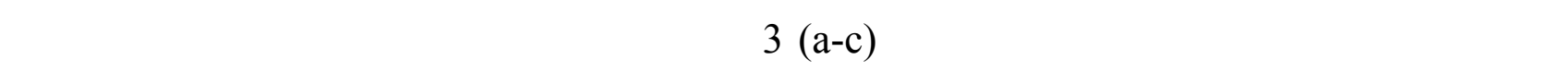

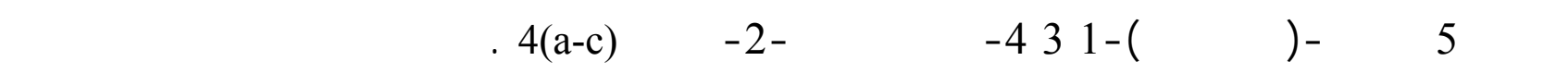

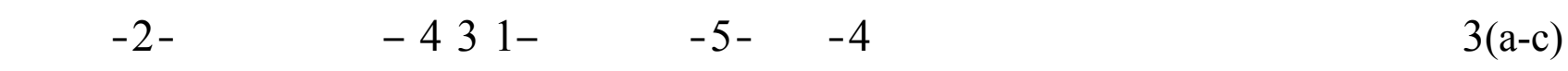

$$
\text { .5(a-c)(ثائر ) }
$$

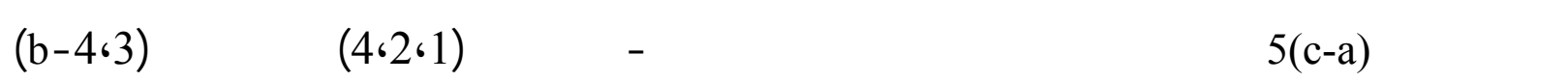

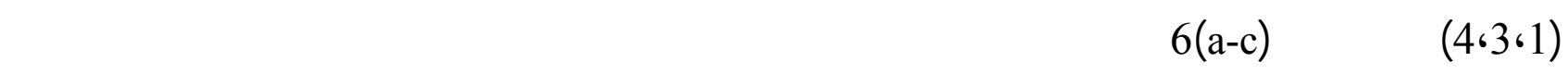

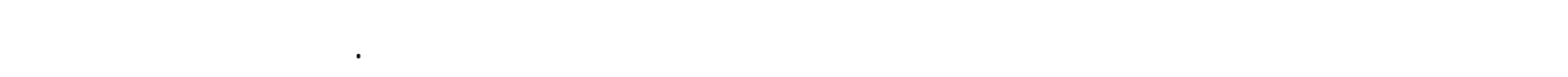

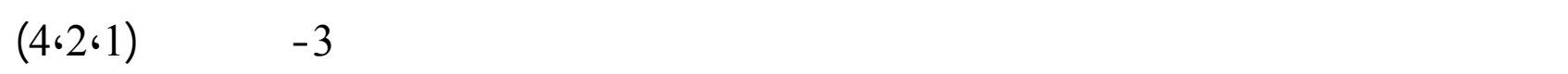

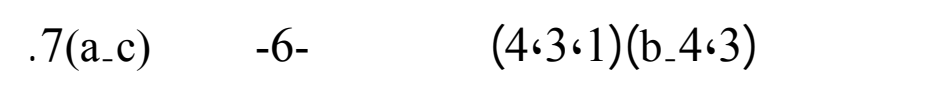

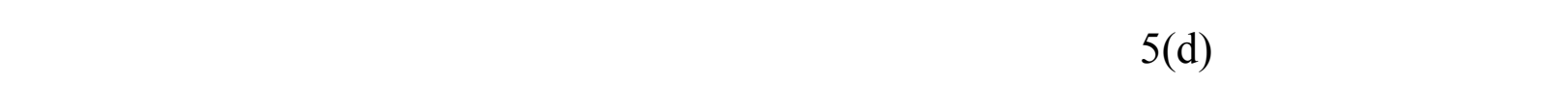

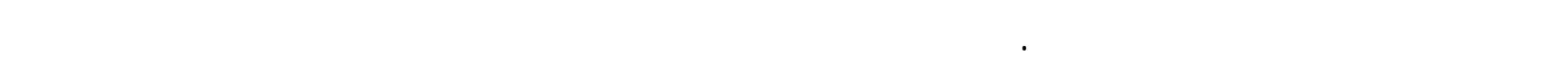

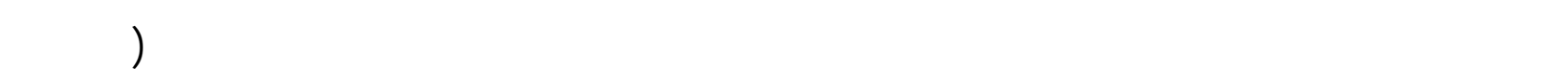

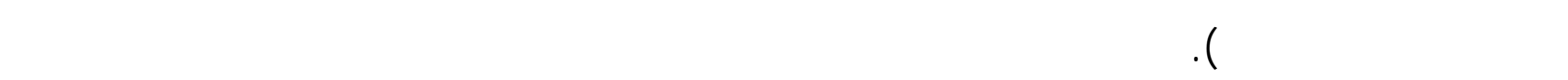

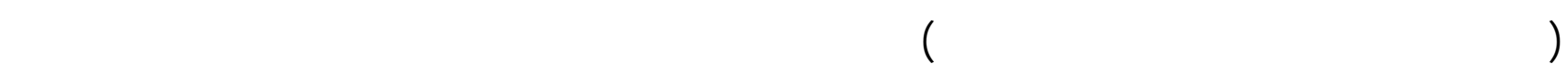
البكتريا.

\section{INTRODUCTION}

As part of the continuous program directed toward the synthesis of important heterocyclic compounds, oxygenous and nitrogenous five and six membered rings (Saied et al., 2010), it was became of interest to investigate the preparative routs to synthesize the title fused heterocyclic compounds. All the target analogues heterocyclic compounds have been reported to exert notably antibacterial activity (Subramanian et al., 2009). 
Also, new series of 1,3,4-thiadiazole-thione derivatives were synthesized and tested for their antibacterial activities. It was therefore thought worthwhile to incorporate the oxadiazole, thiadiazole and or triazole moieties into the title Bridge-head nitrogen.

Semicarbazides were prepared by condensing carbamates with hydrazine hydrate (Mruthunjayaswamy et al., 2009), these carbamate esters were prepared by the reaction of appropriate amines with ethyl chloroformate. It was worthy to mention that semicarbazides converted to carbodithioate salts or cyclized to oxadiazole- 2- thiones by the same reagents (carbon disulfide and potassium hydroxide solution in ethanol), but by two different procedures, while the former involved the agitation at room temperature of the reaction mixture which led to precipitate of quantitative yield of potassium salt which was used in the next step without further purification (Joshi et al., 1989). The latter was carried out by heating the reaction mixture until the evolution of hydrogen sulphide was ceased. These procedures were very popular since ease in workup and high yields were consistently observed but with long reaction time (Somani and Shirodkar, 2009).

Bridge-head nitrogen heterocycles were obtained either by cyclization of these salts with hydrazine hydrate in refluxing ethanol then mixing the triazole products with carboxylic acids at room temperature (Hirpara et al., 2003) or by refluxing ethanolic solution of amidothiosemicarbazides with acetyl acetone (Al-Abdullah, 2007).

Microwave irradiation was introduced as a useful alternative to the traditional heating for the synthesis of several heterocyclic derivatives with high yields and short reactions time. Some 1,2,4-triazolo [3,4-b][1,3,4] thiadiazoles were recently prepared through the reaction of 4-amino-3-mercapto-1,2,4-triazoles with carboxylic acid or aldehydes under microwave irradiations (Al-Abdullah, 2007).

\section{EXPERIMENTAL}

All melting points were determined on a Gallen Kamp and Electro thermal 1A9300 Digital-Series (1998) apparatus and were uncorrected. The IR spectra ( $\mathrm{v} \mathrm{cm}^{-1}, \mathrm{KBr}$ disc) were recorded on Perkin - Elmer 590B Spectrophotometer. UV measurements were carried out on Shimadzu UV-160 spectrophotometer using EtOH as a solvent. NMR spectra were obtained on a BRUKER AVANCE DPX $400 \mathrm{MHz}$. spectrophotometer as $\mathrm{d}_{6}$-DMSO or $\mathrm{CdCl}_{3}$ solutions using TMS as an internal standard at the Department of Chemistry, Donnan and Robert Robinson Laboratories, University of Liverpool, U.K. Finally, microwave irradiation was performed using unmodified domestic Samsung oven (300 MHz).

\section{Ethyl substituted carbamates 1(a-d): (Mruthunjayaswamy et al., 2009)}

Ethyl chloroformate $(10.8 \mathrm{gm}, 0.01 \mathrm{~mole})$ was added drop-wise to a solution of $(0.01$ mole) of the proper amine in $15 \mathrm{ml}$ pyridine. The reaction mixture was left aside at room temperature for an hour with occasional shaking. It was then poured on $100 \mathrm{ml}$ ice water and the precipitated carbamate was filtered, washed with water, dilute hydrochloric acid, then water again and crystallized from aqueous ethanol.

Starting from 5-(4-aminophenyl)-1,3,4-thiadiazol-2-amine and duplicated the scales of the reactant ethyl chloroformate afforded ethyl 4-(5-(ethylcarbamate)-1,3,4-thiadiazol-2-yl) phenylcarbamate $1(\mathrm{~d})$.

${ }^{1} \mathrm{H}$ NMR (DMSO- $\mathrm{d}_{6}, \delta \mathrm{ppm}$ ) for ethyl thiazol-5-yl carbamate $1(\mathrm{~b})$ as a representative of these compounds: $11.68(\mathrm{~s}, 1 \mathrm{H}, \mathrm{NH}), 7.38$ and 7.17(two s, $2 \mathrm{H}$, thiazole ring), $2.12(\mathrm{q}, 2 \mathrm{H}$, $\left.\mathrm{CH}_{2}\right)$ and $1.25\left(\mathrm{t}, 3 \mathrm{H}, \mathrm{CH}_{3}\right)$, other physical and spectral data were listed in Table (1). 
Table 1 : Physical and spectral data of compounds 1(a-d).

\begin{tabular}{|c|c|c|c|c|c|c|}
\hline \multirow{2}{*}{$\begin{array}{l}\text { Comp. } \\
\text { No. }\end{array}$} & \multirow{2}{*}{$\begin{array}{l}\text { M.P. } \\
{ }^{\circ} \mathrm{C}\end{array}$} & \multirow{2}{*}{$\begin{array}{c}\text { Yield } \\
\%\end{array}$} & \multicolumn{3}{|c|}{ IR, KBr, v $\left(\mathrm{cm}^{-1}\right)$} & \multirow{2}{*}{$\begin{array}{c}\text { UV } \\
\text { MeOH } \\
\lambda_{\max }(\mathrm{nm})\end{array}$} \\
\hline & & & NH & $\mathbf{C}=\mathbf{O}$ & $\mathbf{C}=\mathbf{N}$ & \\
\hline $1 \mathrm{a}$ & $189-91$ & 66 & 3162 & 1727 & 1636 & 206 \\
\hline $1 b$ & $139-41$ & 66 & 3184 & 1728 & 1596 & 250 \\
\hline $1 \mathrm{c}$ & $92-4$ & 57 & 3186 & 1722 & 1620 & 242 \\
\hline $1 d$ & $192-94$ & 44 & 3190 & 1728 & 1620 & 260 \\
\hline
\end{tabular}

N-substituted semicarbazides 2(a-d), (Mruthunjayaswamy et al., 2009)

A mixture of (0.01 mole) of appropriate carbamate 1(a-c), excess of hydrazine hydrate $(80 \%)$ and triethyl amine $(1 \mathrm{ml}$.) in ethanol was stirred for an hour, then poured on ice-water and acidified with diluted $\mathrm{HCl}$. The precipitate was filtered and washed with water and crystallized from ethanol.

Starting from compound 1(d) (33.64gm, 0.01 mole) and duplicated the scales of other reactants afforded N-(4-(5-(hydrazinecarboxamido)-1,3,4-thiadiazol-2-yl)phenyl)hydrazine carboxamide 2(d).

${ }^{1} \mathrm{HNMR}$ (DMSO- $\mathrm{d}_{6}, \delta \mathrm{ppm}$ ) for compound $2(\mathrm{~b})$ as a representative of these compounds: 7.90 (s, 2H, thiazol ring), 7.46 (two s, $2 \mathrm{H}, \mathrm{NHCONH}$ ) and $2.25\left(\mathrm{~s}, 2 \mathrm{H}, \mathrm{NH}_{2}\right.$ ), other physical and spectral data were listed in Table (2).

Table 2: Physical and spectral data of compounds 2(a-d).

\begin{tabular}{|c|c|c|c|c|c|c|c|}
\hline \multirow{2}{*}{$\begin{array}{l}\text { Comp. } \\
\text { No. }\end{array}$} & \multirow{2}{*}{$\underset{{ }^{\circ} \mathrm{C}}{\mathrm{M} . P .}$} & \multirow{2}{*}{$\begin{array}{c}\text { Yield } \\
\%\end{array}$} & \multicolumn{4}{|c|}{ IR, KBr, v $\left(\mathrm{cm}^{-1}\right)$} & \multirow{2}{*}{$\begin{array}{c}\mathrm{UV} \lambda_{\max } \\
(\mathrm{nm}) \mathrm{MeOH}\end{array}$} \\
\hline & & & $\mathrm{NH}_{2}$ & NH & $\mathrm{C}=\mathbf{O}$ & $\mathrm{C}=\mathrm{N}$ & \\
\hline $2 \mathrm{a}$ & $169-71$ & 87 & 3240 & 3163 & 1672 & 1637 & 276 \\
\hline $2 b$ & $150-52$ & 76 & 3182 & 3124 & 1673 & 1639 & 254 \\
\hline $2 \mathrm{c}$ & $188-90$ & 46 & 3227 & 3102 & 1673 & 1610 & 238 \\
\hline $2 d$ & $219-21$ & 80 & 3240 & 3166 & 1697 & 1610 & 280 \\
\hline
\end{tabular}

\section{Potassium (2-arylcarbamoyl) hydrazine carbodithioates 3(a-d).}

Carbon disulphide (11.4 g, 0.15 mole) was added dropwise to a solution of proper semicarbazide 2(a-c) ( 0.1 mole) and potassium hydroxide ( $8.4 \mathrm{~g}, 0.15$ mole) in ethanol (250 $\mathrm{ml})$. The mixture was stirred at room temperature for 30 minutes. Dry ether $(200 \mathrm{ml})$ was then added to the mixture and the precipitate was filtered, washed with ether and dried to yield the title salts which were used without further purification in the next step.

Starting from 2(d) $(0.15$ mole $)$ and duplicated the scales of other reactants afforded potassium 2-(4-(5-(2-dithiocarboxylatohydrazinecarboxamido)-1,3,4-thiadiazol-2-yl) phenyl carbamoyl) hydrazine carbodithioate (3d). 
5- Arylamino-1,3,4-oxadiazole-2(3H)-thioles 4(a-c). (Al-Abdullah, 2007)

Carbon disulphide ( $11.4 \mathrm{~g}, 0.15$ mole) was added dropwise to a solution of appropriate semicarbazide 2(a-c) (0.1 mole) and potassium hydroxide ( $8.4 \mathrm{~g}, 0.15$ mole) in ethanol (250 $\mathrm{ml}$ ), The mixture was refluxed for $6 \mathrm{hrs}$, concentrated and acidified with diluted $\mathrm{HCl}$. The resulted solid was collected, washed with water and recrystallized from a mixture of DMF$\mathrm{H}_{2} \mathrm{O}$.

${ }^{1} \mathrm{HNMR}\left(\mathrm{DMSO}-\mathrm{d}_{6}, \delta \mathrm{ppm}\right)$ for compound 4(a): $12.32(\mathrm{~s}, 1 \mathrm{H}, \mathrm{SH}), 7,54-7.92(\mathrm{~m}, 5 \mathrm{H}$, Ar) and 4.26.(s,1H,NH), while that for compound 4(b):11.96 (s, 1H, SH), 7.16 and 7.37(s, $2 \mathrm{H}$, thiazole ring) and $4.12(\mathrm{~s}, 1 \mathrm{H}, \mathrm{NH})$ respectively, other physical and spectral data were listed in Table (3).

Table 3: Physical and spectral data of compounds 4(a-c).

\begin{tabular}{|c|c|c|c|c|c|c|}
\hline \multirow{2}{*}{$\begin{array}{c}\text { Comp. } \\
\text { No. }\end{array}$} & \multirow{2}{*}{$\begin{array}{c}\text { M.P. } \\
{ }^{\circ} \mathbf{C}\end{array}$} & \multirow{2}{*}{$\begin{array}{c}\text { Yield } \\
\%\end{array}$} & \multicolumn{3}{|c|}{$\mathrm{IR}, \mathrm{KBr}, \mathrm{v}\left(\mathrm{cm}^{-1}\right)$} & \multirow{2}{*}{$\begin{array}{c}\mathrm{UV} \lambda_{\max } \\
(\mathrm{nm}) \\
\mathrm{MeOH}\end{array}$} \\
\hline & & & NH & $\mathbf{C}=\mathbf{N}$ & $\mathbf{C}=\mathbf{S}$ & \\
\hline $4 a$ & $187-88$ & 75 & 3155 & 1600 & 1280 & 288 \\
\hline $4 \mathrm{~b}$ & $142-44$ & 85 & 3183 & 1620 & 1254 & 298 \\
\hline $4 c$ & $202-04$ & 80 & 3180 & 1610 & 1250 & 240 \\
\hline
\end{tabular}

4-Amino-5-aryl amino-1,2,4-triazole-3-thiones (thioles) 5(a-d). (El-Emam et al., 1993)

A solution of a proper potassium salt $3(\mathrm{a}-\mathrm{c})(0.01 \mathrm{~mole})$ in ethanol $(150 \mathrm{ml})$ was refluxed with (0.6 mole) hydrazine hydrate. A precipitate was obtained in 3-5 minutes, and the refluxing of the mixture was continued for 3 hours. On cooling, water $(100 \mathrm{ml})$ was added and the mixture was neutralized with $10 \%$ hydrochloric acid and allowed to stand for three hours. The separated product was filtered, washed with water, dried and crystallized from ethanol to yield the title compounds.

Starting from (3d) (0.01 mole) and duplicated the scales of other reactants afforded 4amino-3-(4-(5-(4-amino-5-thioxo-4,5-dihydro-1H-1,2,4-triazol-3-ylamino)-1,3,4-thiadiazol2-yl)phenylamino)-1H-1,2,4-triazole-5(4H)-thione (5d).

${ }^{1} \mathrm{HNMR}\left(\mathrm{DMSO}-\mathrm{d}_{6}, \delta \mathrm{ppm}\right)$ for compound 5(c) as a representative of these series: 9.00 $(\mathrm{s}, 1 \mathrm{H}, \mathrm{SH}), 7.50-7.92(\mathrm{~m}, 5 \mathrm{H}, \mathrm{ArH}$ and $\mathrm{NH})$ and $4.26\left(\mathrm{~s}, 2 \mathrm{H}, \mathrm{NH}_{2}\right)$, other physical and spectral data were listed in Table (4).

Table 4: Physical and spectral data of compounds 5(a-c).

\begin{tabular}{|c|c|c|c|c|c|c|c|}
\hline \multirow{2}{*}{$\begin{array}{c}\text { Comp. } \\
\text { No. }\end{array}$} & \multirow{2}{*}{$\begin{array}{l}\text { M.P. } \\
{ }^{\circ} \mathrm{C}\end{array}$} & \multirow{2}{*}{$\begin{array}{c}\text { Yield } \\
\%\end{array}$} & \multicolumn{4}{|c|}{ IR, KBr , v $\left(\mathrm{cm}^{-1}\right)$} & \multirow{2}{*}{$\begin{array}{c}\mathrm{UV} \lambda_{\max }(\mathrm{nm}) \\
\mathrm{MeOH}\end{array}$} \\
\hline & & & $\mathbf{N H}_{2}$ & NH & $\mathbf{C}=\mathbf{N}$ & $\mathbf{C}=\mathbf{S}$ & \\
\hline $5 a$ & $182-83$ & 37 & 4403 & 3055 & 1628 & 1210 & 300 \\
\hline $5 b$ & $190-92$ & 40 & 3350 & 3155 & 1627 & 1210 & 300 \\
\hline $5 c$ & $178-80$ & 44 & 3324 & 3166 & 1622 & 1210 & 288 \\
\hline $5 d$ & $218-20$ & 75 & 3350 & 3163 & 1628 & 1210 & 298 \\
\hline
\end{tabular}




\section{Synthesis of authentic sample:}

4-amino-5-(3-pyridyl)amino- 1,2,4- triazole-3-thiole 5(c). (Farghaly et al., 2007)

A mixture of 5-(pyridin-3-ylamino)-1,3,4-oxadiazole-2(3H)-thione (4c) (0.01 mole) and excess of hydrazine hydrate $(80 \%)$ in ethanol was refluxed for three hours, then poured on ice-water. The precipitate was filtered, washed with water and crystallized from ethanol. The product has same melting point of compound 5(c) prepared by previous general procedure.

\section{3-(Arylamino)-[1,2,4] triazolo[3,4-b][1,3,4]thiadiazoles 6 (a-c):}

Conventional method(A). (Fiona et al., 2008)

A mixture of proper compound $5(\mathrm{a}-\mathrm{c})(0.01 \mathrm{~mole})$ and formic acid $(0.46 \mathrm{ml}, 0.01 \mathrm{~mole})$ in benzene $(10 \mathrm{ml})$ was refluxed for three hours. After evaporating the solvent under reduced pressure, an oily product was obtained which was crystallized from $\mathrm{DMF}-\mathrm{H}_{2} \mathrm{O}$ (1:1) to afford the title compound. ${ }^{1} \mathrm{H}$ NMR (DMSO- $\left.\mathrm{d}_{6}, \delta \mathrm{ppm}\right)$ for $6(\mathrm{a})$ as a representative compound of these series: $12.3(\mathrm{~s}, 1 \mathrm{H}$, fused thiazole ring), 7.54-7.92(m, 5H, ArH) and $4.27(\mathrm{~s}, 1 \mathrm{H}, \mathrm{NH})$, other physical and spectral data were listed in Table (5).

Irradiation method B: (Omprakash et al., 2011)

A mixture of proper compound $5(\mathrm{a}-\mathrm{c})(0.01 \mathrm{~mole})$ and formic acid $(0.46 \mathrm{ml}, 0.01 \mathrm{~mole})$ was placed in $25 \mathrm{ml}$ open round bottom flask and irradiated in the microwave oven for 4 minutes. On cooling, an oily product was obtained which was worked up as in method (A).

Table 5: Physical and spectral data of compounds 6(a-c).

\begin{tabular}{|c|c|c|c|c|c|c|}
\hline \multirow{3}{*}{$\begin{array}{c}\text { Comp. } \\
\text { No. }\end{array}$} & \multirow{3}{*}{$\begin{array}{c}\text { M.P. } \\
{ }^{\circ} \mathrm{C}\end{array}$} & \multirow{2}{*}{\multicolumn{2}{|c|}{$\begin{array}{l}\text { Yield \% } \\
\text { Method }\end{array}$}} & \multicolumn{2}{|c|}{ IR, $\mathrm{KBr}, \mathrm{v}\left(\mathrm{cm}^{-1}\right)$} & \multirow{3}{*}{$\begin{array}{c}\mathrm{UV} \lambda_{\max } \\
(\mathrm{nm}) \\
\mathrm{MeOH}\end{array}$} \\
\hline & & & & \multirow[t]{2}{*}{ NH } & \multirow[t]{2}{*}{$\mathrm{C}=\mathrm{N}$} & \\
\hline & & $\mathbf{A}$ & B & & & \\
\hline $6 a$ & 201-02 & 37 & 90 & 3149 & 1556 & 320 \\
\hline $6 b$ & $188-90$ & 40 & 90 & 3155 & 1556 & 330 \\
\hline $6 c$ & 194- 69 & 44 & 92 & 3155 & 1566 & 320 \\
\hline
\end{tabular}

\section{3-(5-Arylamino) $[1,2,4]$ triazolo[3,4-b][1,3,4]thiadiazole-6-thiones 7(a-c). (Fiona et al.,} 2008)

To a solution of the proper 4-amino-5-arylamino-1,2,4-triazole-3-thiol 5(a-c) $(0.001$ mole) in ethanol $20 \mathrm{ml}, \mathrm{KOH}(0.5 \mathrm{gm})$ and $\mathrm{CS}_{2}(1 \mathrm{ml})$ were added and the mixture was refluxed for 2 hours. The solvent was removed under reduced pressure. Ice-water was added to the reaction mixture with stirring. The solid was separated, washed with water and crystallized from ethanol to afford the title compound.

${ }^{1} \mathrm{H}$ NMR $\left(\mathrm{CDCl}_{3}, \delta \mathrm{ppm}\right)$ for compound $7(\mathrm{a})$ as a representative of this series: $7.50-7.94$ $(\mathrm{m}, 5 \mathrm{H}, \mathrm{ArH})$ and $4.42(\mathrm{~s}, 2 \mathrm{H}, 2 \mathrm{NH})$, other physical and spectral data were listed in Table (6). 
Table 6: Physical and spectral data of compounds 7(a-c).

\begin{tabular}{|c|c|c|c|c|c|c|}
\hline \multirow{2}{*}{$\begin{array}{l}\text { Comp. } \\
\text { No. }\end{array}$} & \multirow{2}{*}{$\begin{array}{l}\text { M.P. } \\
{ }^{\circ} \mathrm{C}\end{array}$} & \multirow{2}{*}{$\begin{array}{l}\text { Yield } \\
\%\end{array}$} & \multicolumn{3}{|c|}{$\mathrm{IR}, \mathrm{KBr}, \mathrm{v}\left(\mathrm{cm}^{-1}\right)$} & \multirow{2}{*}{$\begin{array}{c}\mathrm{UV} \lambda_{\max }(\mathrm{nm}) \\
\text { MeOH }\end{array}$} \\
\hline & & & NH & $\mathrm{C}=\mathrm{N}$ & $\mathrm{C}=\mathrm{S}$ & \\
\hline $7 a$ & $121-23$ & 37 & 3182 & 1600 & 1272 & 326 \\
\hline $7 \mathrm{~b}$ & 164- 66 & 40 & 3155 & 1600 & 1272 & 333 \\
\hline $7 \mathrm{c}$ & 186- 88 & 44 & 3186 & 1620 & 1278 & 322 \\
\hline $7 d$ & $175-77$ & 75 & 3186 & 1620 & 1278 & 310 \\
\hline
\end{tabular}

\section{Biological Test}

All the synthesized compounds in the present investigation were screened for their antibacterial activity by subjecting the compounds to a standard procedure. Antibacterial activities were tested on nutrient medium against Staphylococcus, Streptococcus and Salmonella. The antibacterial activity of the compounds was assessed by disc diffusion method. The extent diameter of inhibition after 24 hours was measured as the zone of inhibition in millimeters.

\section{RESULTS AND DISCUSSION}

A convenient synthesis of target compounds were accomplished by the routes outlined in Schemes (1 and 2). Ethyl substituted carbamates 1(a-c) were prepared from ethylchloroformate and a suitable amines. The IR spectra of these compounds showed broad bands at around $3190-3162 \mathrm{~cm}^{-1}$ due to NH bond stretching while a strong bands at $1722-1728 \mathrm{~cm}^{-1}$ was attributed to $\mathrm{C}=\mathrm{O}$ bond stretching carbonyl group and at $1596-1636$ $\mathrm{cm}^{-1}$ related to aromatic heterocyclic $\mathrm{C}=\mathrm{N}$. (Table 1 ). The ${ }^{1} \mathrm{HNMR}$ spectra were supporting the presence of two thiazole protons around $\delta 7.17$ and $7.38 \mathrm{ppm}$, while the $\mathrm{NH}$ proton appeared as a singlet signal at $\delta 11.68$. The $\mathrm{CH}_{2}$ protons appeared quartet at $\delta 2.12 \mathrm{ppm}$ and the $\mathrm{CH}_{3}$ appeared as triplet at $\delta 2.12 \mathrm{ppm}$.

The key intermediates N-substituted semicarbazides 2(a-d) were prepared by hydrazinolysis of carbamates $1(\mathrm{a}-\mathrm{c})$ with hydrazine hydrate (Varvounisa and Giannopoulos, 1996). The IR spectra showed broad stretching vibrations at around $3240-3182 \mathrm{~cm}^{-1}$ due to $\mathrm{NH}_{2}$ and a strong band at $1697-1672 \mathrm{~cm}^{-1}$ attributed to amide carbonyl and at $1639-1610 \mathrm{~cm}^{-1}$ due to aromatic heterocyclic $\mathrm{C}=\mathrm{N}$, (Table 2). The ${ }^{1} \mathrm{HNMR}$ spectra were introducing an evidence to the presence of the two thiazole protons appeared around 87.90 ppm, and the NHCONH protons appeared multiplet at $\delta 7.46 \mathrm{ppm}$, the semicarbazide terminal nitrogen protons appeared doublet at $\delta 2.25 \mathrm{ppm}$.

Refluxing the ethanolic solution of these intermediates with ethanolic solution of carbon disulfide afforded 5-arylamino-1,3,4-oxadiazole-2(3H)-thioles 4(a-c) (Varvounisa and Giannopoulos, 1996). The IR spectra showed broad stretching band at (3155-3186 $\left.\mathrm{cm}^{-1}\right)$ for $\mathrm{NH},\left(1600-1620 \mathrm{~cm}^{-1}\right)$ for $\mathrm{C}=\mathrm{N}$ and at $\left(1280-1254 \mathrm{~cm}^{-1}\right)$ of $\mathrm{C}=\mathrm{S}$, Table (3). The ${ }^{1} \mathrm{HNMR}\left(\mathrm{d}_{6} \mathrm{DMSO}\right.$ ) of compound 4(a) was characterized by the presence of the one SH proton appeared as a singlet signal at $\delta 12.32 \mathrm{ppm}$, five aromatic protons appeared as multiplet at 7.16-7.37 ppm, two thiazole protons appeared around $\delta 7.16$ and $7.37 \mathrm{ppm}$, while the NH proton appeared as singlet at $\delta 4.26 \mathrm{ppm}$. The ${ }^{1} \mathrm{HNMR}\left(\mathrm{DMSO}-\mathrm{d}_{6}, \delta \mathrm{ppm}\right.$ ) for 
compound 4(b) proves the presence of the one SH proton appeared as singlet at $\delta 11.96$ $\mathrm{ppm}$, two thiazole protons appeared around $\delta 7.16$ and $7.37 \mathrm{ppm}$, while the NH proton appeared as a singlet signal at $\delta 4.12 \mathrm{ppm}$. Changing these conditions to strong basic conditions at room temperature, followed by acidification with dilute hydrochloric acid resulted in the formation of the corresponding potassium (2-arylcarbamoyl) hydrazine carbodithioates 3(a-c). These salts were cyclized with hydrazine hydrate to 4-amino-5arylamino-1,2,4triazole-3-thioles 5(a-d) (El-Emam et al.,1996).



$\mathrm{N} N$ 
These compounds were present in thione-thiol tautomeric forms, (Scheme 2). the ultraviolet spectra of methanolic solution of these triazoles showed absorption bands at 288-300 nm due to the presence of the chromophoric $\mathrm{C}=\mathrm{S}$ group (Fiona et al., 2008).

The IR spectram disclosed the presence of $\mathrm{C}=\mathrm{S}$ at $\left(1210 \mathrm{~cm}^{-1}\right)$ which was responsible to those thiones in addition to $\mathrm{C}=\mathrm{N}$ bands at $\left(1678-1672 \mathrm{~cm}^{-1}\right), \mathrm{NH}\left(3166-3055 \mathrm{~cm}^{-1}\right)$ and of a primary amine bands at $\left(3440-3324 \mathrm{~cm}^{-1}\right)$ with no absorbance at $\left(2600-2400 \mathrm{~cm}^{-1}\right)$ of thiole form, (Table 4) (Almajan et al., 2008). These results did not agree with the ${ }^{1} \mathrm{HNMR}$ $\left(\mathrm{DMSO}_{-} \mathrm{d}_{6}, \delta \mathrm{ppm}\right)$ for compound $5(\mathrm{c})$ which was characterized by presence of the one SH proton appeared as singlet at $\delta 12.30 \mathrm{ppm}$ and four aromatic protons with $\mathrm{NH}$ proton appeared as multiplet around $\delta 7.50-7.92 \mathrm{ppm}$, while the $\mathrm{NH}_{2}$ proton appeared as singlet at $\delta 4.26 \mathrm{ppm}$, indicated that the thiole tautomer was existed predominantly in DMSO solution. This result was due to solvent effects (Looker et al.,1978). (Scheme 2). Thiol-thione tautomerism exists in compounds $5(\mathrm{a}-\mathrm{c})$, in the ${ }^{1} \mathrm{HNMR}$ the signal of the SH proton was recorded, and as it has been reported that the crystal structures of these compounds correspond to the thione form, but they showed thiol-thione tautomerism in solution (Koparir et al., 2005).

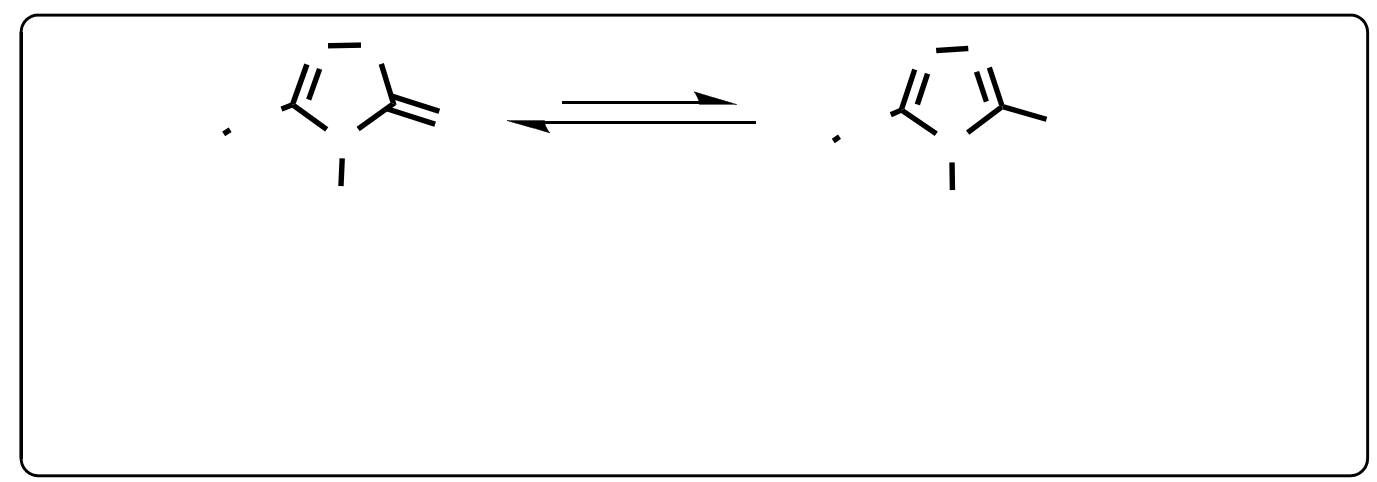

As the structural skeleton of compounds 5(a-c) was established spectroscopically, the chemical behavior of these compounds was also used for assigning their structure, as expected it was found that refluxing of compound 4(c) with carbon disulfide under strong basic conditions followed by acidification with dilute hydrochloric acid resulted in the formation of the authentic sample 5(c) (Artemov and Shvaika, 2008).

The formation of the same product from two different compounds indicated the correct assignment for these compounds.

These 4-amino-5-mercapto-3-arylamine-1,2,4-triazoles 5(a-d) were excellent precursors for the synthesis of bridge-head nitrogen heterocyclic and have received much attention during recent years (Omprakash et al., 2011). Thus in this study, 3-(5-aryl-1,3,4thiadiazol-2-ylamino-[1,2,4] triazolo [3,4-b] $[1,3,4]$ thiadiazoles $6(\mathrm{a}-\mathrm{c})$ were synthesized by dehydrative ring closure through heating of corresponding triazole with formic acid in presence of benzene solution of phosphorus oxychloride (Mathew et al., 2006). The method (A) gave low yield, but can be improved to $95 \%$ with short time microwave irradiation to 4 minutes (Omprakash and Anjaneyulu; 2001). The IR, $v\left(\mathrm{~cm}^{-1}\right)$ of this compound was : 3149 - $3155(\mathrm{NH})$ and 1566-1555 $(\mathrm{C}=\mathrm{N})$ in addition to the disappearance of the absorption exocyclic of thione $\left(1726 \mathrm{~cm}^{-1}\right)$. Ne ${ }^{1} \mathrm{H} N \mathrm{~N}\left(\mathrm{DMSO}-\mathrm{d}_{6}, \delta \mathrm{ppm}\right)$ for compound 6(a) was characterized by the presence of the one thiadiazole fused ring proton

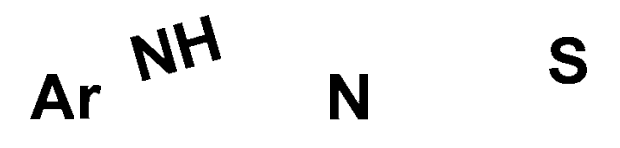


appeared as singlet at $\delta 9.00 \mathrm{ppm}$, five aromatic protons appeared as multiplet around $\delta 7.54$ $-7.92 \mathrm{ppm}$, whereas the $\mathrm{NH}$ proton appeared as singlet at $\delta 4.27 \mathrm{ppm}$.

Also, refluxing of triazoles 5(a-c)with carbon disulfide under basic conditions afforded 3-(5-arylmino)-[1,2,4]triazolo[3,4-b][1,3,4]thiadiazole-6-thiones 7(a-c) (Varvounisa and Giannopoulos, 1996). This reaction was very popular since ease in workup and high yields (>90\%) were consistently observed.

The IR spectral data of these compounds confirmed their existence in the thione form. The characteristic absorption peaks at 3186-3155 $\mathrm{cm}^{-1}(\mathrm{NH}), 1278-1272 \mathrm{~cm}^{-1}(\mathrm{C}=\mathrm{S})$ and $1620-1600 \mathrm{~cm}^{-1}(\mathrm{C}=\mathrm{N})$ were observed. The ${ }^{1} \mathrm{H} \mathrm{NMR}\left(\mathrm{CDCl}_{3}, \delta \mathrm{ppm}\right)$ for compound $7(\mathrm{a})$ was characterized by the presence of the five aromatic protons appeared as multiplet around $\delta 7.54-7.94 \mathrm{ppm}$, also the two $\mathrm{NH}$ groups protons (of fused ring and $\mathrm{NH}$ ) appeared as singlet at $\delta 4.421 \mathrm{ppm}$ The two diazole ring protons indicated the thione isomer was the predominate.

Finally, 4-amino-3-(4-(5-(4-amino-5-thioxo-4,5-dihydro1- H-1,2,4-triazol-3-ylamino)1,3,4-thiadiazol-2-yl)phenylamino)-1H-1,2,4-triazole-5(4H)-thiole $5(\mathrm{~d})$ was synthesized by the same procedures that were followed to synthesize its analogues starting from 5-(4aminophenyl)-1,3,4-thiadiazol-2-amine and duplicated all the scales of the reactants. (Scheme 3). The UV and IR spectral data of these compounds showed similar patterns to those of triazoles-5-thioles 5(a-c). (Tables 1- 6).

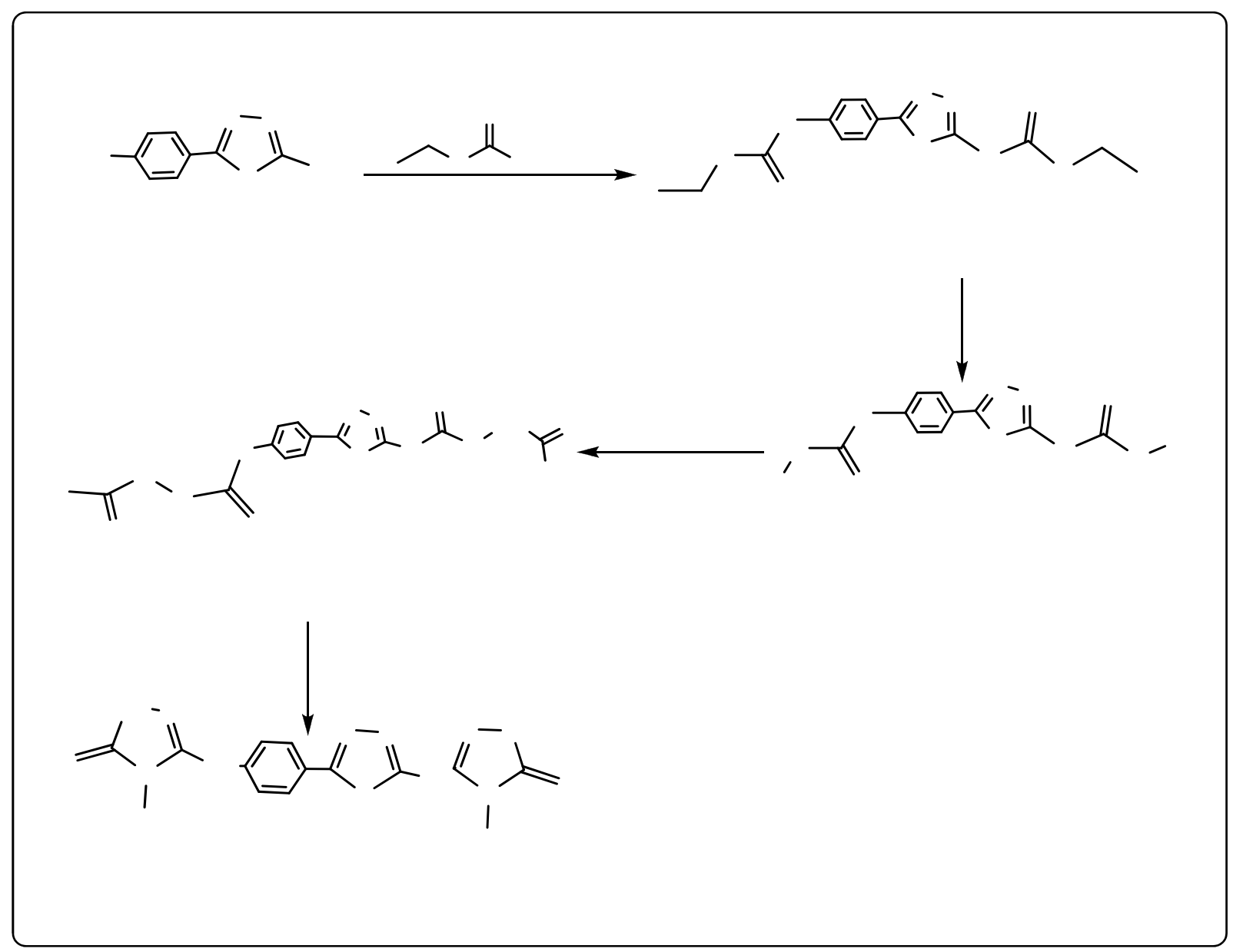


All the synthesized compounds were tested for their in vitro growth inhibitory activity against a panel of standard strains of pathogenic microorganism including bacteria Staphylococcus, Streptococcus and Salmonella.

All these compounds were practically inactive against the tested microorganisms.

\section{ACKNOWLEDGEMENTS}

The author wishes to express his gratitude for (the 1H NMR spectra) financial support from COUNCIL FOR ASSISTING REFUGEE ACADEMICS (cara), Iraq Programme and Dr Jonathan Iggo, Senior Lecturer in Inorganic Chemistry, Department of Chemistry, Donnan and Robert Robinson Laboratories, University of Liverpool, Liverpool, L69 7ZD, for their help in ${ }^{1} \mathrm{H}$ NMR analysis. Many thanks to Kate Robertson, Deputy Executive Secretary. He also thanks Dr. Nawal A. Alubaidy, Veterinary Medicinal College of Mosul for her help in the evaluation of antibacterial activities.

\section{REFERENCES}

Al-Abdullah, E.S. (2007). Synthesis and biological testing of new 1-adamantyl derivatives. PhD. thesis; King Saud University; KSA.

Almajan, J.L. M. ( 2008). Studies in penta atomic heterocyclic compounds 1,3,4-oxadiazole and 1,2,4 - Triazoles with potential biological action. PhD. Thesis, University of Medicine and Pharmacy "Carol Davila". Bucharest (Roman).

Artemov, V.N.; Shvaika, O.P. (2008). Recyclization reactions of heterocyclic compounds involving hydrazine and its substituted derivatives. Chem. Heterocyclic Compounds., 7, 844-48.

El-Emam, A. A.; Moustafa, M. A.; Abdelal, A. M.; El-Ashmawy, A. B. (1993). Synthesis, metabolic behaviour and antibacterial activity of new sulfanilamide pyrazoles. Chin. Pharm. J., 45, 101-107.

Farghaly, A.; Clercq, E. D.; El-Kashef, H. (2006). Synthesis of some new azoles of antiviral potentiall. ARKIVOC, (x), 137-51.

Fiona, N. F.; How, K.A; Crouse, M.; Ibrahim, M.; Tarafder, M.T.H.; Andrew, R.C. (2008). Synthesis, characterization and biological studies of S-benzyl-b-N-(benzoyl) dithiocarbazate and its metal complexes. Polyhedron, 27(15), 3325-3329.

Hirpara, H. M.; Sodha, V. A.; Trivedi, A. M.; Khatri, B. L.; Parikh, A. R. (2003). Reactions of 17a,21-dichloro-20-oxopregnanes and their derivatives. Indian J. Chem., 42(B), 1756-1759.

Joshi, S. D.; Vagdevi, H. M. ; Vaidya, V. P.; Gadaginamath, G. S. (1983). Synthesis of new 4-pyrrol-1-yl benzoic acid hydrazide analogs and some derived oxadiazole, triazole and pyrrole ring systems: A novel class of potential antibacterial and antitubercular agents. European J. Medicinal Chem., 43.pp 1989- 1996.

Koparır, M.; Çetin, A.; Cansız, A. (2005). 5-Furan-2yl[1,3,4]oxadiazole-2-thiol, 5-Furan2yl-4H[1,2,4]triazole-3-thiol and their thiol-thione tautomerism; Molecules, 10, 475-480

Looker, J.H.; Khatri, N.A.; Patterson, R.B.; Kingsbury, C.A. (1978). Carbon-13 Nmr spectra of 1,2,3-thiadiazoles. J. Heterocycl. Chem., 15, 1383.

Mathew, V.; Keshavayya, J.; Vaidya, V. P. (2006). Heterocyclic system containing bridgehead nitrogen atom: synthesis and pharmacological activities of some 
substituted 1,2,4-triazolo[3,4-b]-1,3,4-thiadiazoles. Eur. J. Med. Chem., 41, 104858.

Mruthunjayaswamy, B.H.M.; Basavarajaiah, S.M. (2009). Synthesis and antimicrobial activity of novel ethyl-5-(ethyoxycarbonyl)-4-methylthiazole-2-yl-carbamate compounds. Ind. J. Chem.; 48(B), 1274-1278.

Omar, F. A.; Mahfouz., N. M.; Rahman, M. A. (1996). Design, synthesis and antiinflammatory activity of some 1,3,4-oxadiazole derivatives. Eur. J. Med. Chem., 31, 819.

Omprakash, G.; Anjaneyulu, Y.; Subramanian, N.S.; Ramadevi, V. R. M.; Gupta, M.; Vijayalakshmi, G. (2011). Synthesis, characterization and anti-microbial screening of novel heterocyclic system containing bridgehead nitrogen atom. RJPBCS ; 2(1), 410.

Saied, Sh. M.; Al-Gawady, M. S.; Sheet, M. A. (2010). Some important reactions of 4aminoantipyrine (4-AAP). J. Raf. Sci., 21(1), 53-64.

Sharba, A. H.; Al-Bayati, R. I.; Aouad , A.; Rezki, N. ( 2005). Synthesis of oxadiazoles, thiadiazoles and triazoles derived from benzo[b]thiophene. Molecules, 10, 11611168.

Somani, R. R. ; Shirodkar, P. Y. (2009). Oxadiazole: A biologically important heterocycle. Der. Pharma. Chem. 1 (1), 130-140.

Subramanian, N.S.; Omprakash, G.; Anjaneyulu, Y.; Gupta, V.; Ramadevi, M. (2009). Synthesis, characterization and anti-microbial screening of novel thiazolidino fused compounds. J. Pharma. and Chem., 3 (3), 91-95.

Varvounisa, G.; Giannopoulos, T. (1996). Synthesis, chemistry, and biological properties of thienopyrimidines. Advances in Heterocyclic Chem. 66, 193-283. 